\title{
A 'historic(al)' find from the library of Herculaneum: Seneca the Elder and the Historiae $a b$ initio bellorum civilium in P.Herc. 1067
}

\begin{abstract}
This article presents in concise but comprehensive fashion the work that led to the identification of the text contained in P.Herc. 1067 as the historical work of Seneca the Elder. After a brief overview of the history of Herculaneum studies, the paper focuses on the new reading of the first line of the subscriptio, which, by allowing us to identify the author as a Lucius Annaeus Seneca, has shown the previous attribution of the text to Lucius Manlius Torquatus, and accordingly its interpretation as an oratio in Senatu habita ante principem, to be incorrect. There follows a description of the roll in bibliological, palaeographical and papyrological terms, as well as a brief presentation of its contents. They are elucidated using the prosopography contained in the papyrus which wholly refers to the Augustan or Tiberian age. The article closes with a detailed description of the second line of the subscriptio which contains the title of the work.
\end{abstract}

\section{The discovery in the context of Herculaneum studies}

The two and a half centuries that separate us from the discovery of the Villa of the Papyri have clearly not been sufficient to exhaust the treasures preserved for millennia by the ashes of Mount Vesuvius. The presence of a work by Seneca the Elder among the carbonized rolls of the only library from classical antiquity to have survived, in part, to our day opens important avenues of research in a number of ways.

\footnotetext{
The research leading to these results has received funding from the European Research Council (ERC) under the European Union's Horizon 2020 research and innovation program (Grant agreement no. 636983); ERC-PLATINUM project, University of Naples 'Federico II', P.I. Maria Chiara Scappaticcio.
}

Ә Open Access. (c) 2020 Valeria Piano, published by De Gruyter. (c) BY-NC-ND This work is licensed under the Creative Commons Attribution-NonCommercial-NoDerivatives 4.0 License. https://doi.org/10.1515/9783110688665-003 
The discovery was made between 2016 and 2017, and confirmed an unpublished palaeographical intuition of Robert Marichal, making possible, in addition, the precise identification of the auctor and a plausible proposal concerning the work in question. ${ }^{1}$ It has come at a very productive time for Herculaneum studies that are leading to the revision of some aspects of the history and the intellectual life of the Villa more generally.

The identification of a work by Seneca the Elder that does not otherwise survive represents an important discovery not only because it allows us to add another piece to the mosaic that is the history of Latin literature; its bibliological and, more generally, historical and cultural significance is considerable. Containing part of a work composed between the end of the 30s and the beginning of the 40 s AD, P.Herc. 1067 is one of the very few books written in Latin language that have survived from the 1st century $\mathrm{AD}$ and that has hitherto been reconstructed. It therefore offers first-hand information on writing practices in the Roman world, at a time when these practices were proliferating for purely literary aims, and public and private libraries were taking shape. Its western provenance, moreover, makes it an even more valuable piece of evidence.

The late date further supports the conclusions reached by archaeological and papyrological evidence which now finally discredits the old hypothesis according to which the Villa in the 1st century AD had lost its former luster and was in a phase of agricultural reconversion. ${ }^{2}$ If anything, the revised chronology of the Villa, the discovery of ongoing renovations in some areas of the complex at the time of the eruption, ${ }^{3}$ the first-century dating of hands that reedited some works of Greek philosophical historiography or restored parts of Philodemus' works ${ }^{4}$ paint a picture of great socio-cultural liveliness. ${ }^{5}$ This impression is confirmed by the observation that the owners of the Villa, in addition to commissioning the restoration or reedition of older Greek rolls, also bought new bookrolls, in Latin, that contained newly-produced works, not of philosophy, but, most interestingly, of recent Roman history.

1 The editio princeps of the text including a comprehensive study of the archives, the anatomy of the roll, the script and the mise en page of the text is Piano (2017a); the preliminary results of the study were presented at the 28th International Congress of Papyrology (Barcelona 2016), now published in Piano (2019).

2 Wójicik (1986) 37.

3 Guidobaldi/Esposito (2009) and, in English, Guidobaldi/Esposito (2010).

4 Del Mastro (2010).

5 For a treatment of the composition of the library and the owners of the Villa that takes into account the consequences of the new dating, see Dorandi (2017a). 
Though it is a single papyrus - among the 124 items in the inventory that make up the pars Latina of the Library $-{ }^{6}$ P.Herc. 1067 joins the only other Latin work from Herculaneum identifiable with certainty from its contents, the Carmen de Bello Actiaco (P.Herc. 817), ${ }^{7}$ in confirming a clear interest in events of contemporary history on behalf of the Pisones who, in all likelihood, owned the Villa.

As will be seen, a remarkable amount of information can be extracted, directly or indirectly, from a single volumen, owing to the unique possibility of studying a literary roll within its original cultural and library context.

\section{Anatomy of the roll, palaeography and mise en page}

Of the original volumen that is missing its upper part, now known as P.Herc. 1067, 16 pezzi remain; ${ }^{8}$ they were obtained through the process of unrolling using the machine invented by Antonio Piaggio in the final decades of the 18th century. ${ }^{9}$ These 16 pezzi are preserved in 10 cornici, numbered from 1 to 9, but, as is frequently the case with the Herculaneum papyri, the numbering of the cornici does not correspond to the original order of the pezzi in the papyrus. The editio princeps established the correct succession of pezzi by studying different kinds of material features and damages visible on the papyrus, that is those folds, fractures and twists that are found consistently in all pezzi, since they are the product of deformations suffered by the roll when it was still rolled up. ${ }^{10}$ Where this data can be collected and assessed, it offers a guide to the reconstruction of the roll, since at least in principle - material damage that occurs while a papyrus is still rolled up

6 To the 120 items reported in Del Mastro (2005) add the four other items (P.Herc. 50, 475, 1586, 1781) classified as Latin papyri from Herculaneum in the website www.chartes.it. Remnants of another Latin papyrus have been found at Pompei; cf. Del Mastro (2018).

7 For this famous volumen cf. now Scappaticcio (2010) and Capasso (2011) 45-61, who provide references to the previous bibliography.

8 Contrary to the claim in CatPErc 254 which registers 15 pezzi. On the consistency of the papyrus within the various Inventories stored at the Officina dei Papiri Ercolanesi “Marcello Gigante", see Piano (2017a) 163-170. In what follows I will use the terms pezzo and cornice as understood in Herculaneum papyrology, to refer to the pieces of an unrolled papyrus and the metal containers in which they are preserved respectively.

9 The archives make clear that P.Herc. 1067 was unrolled in two phases: in 1808 by G. Casanova and in 1820 by V. Orsini.

10 For the definitions of "danno solidale", "volute" (that is circumference), and "sezione di volute" (that is the section of a circumference) cf. Del Mastro (2011) 56 n. 70. 
leaves an imprint on several layers, creating in the pezzi of the opened roll folds that are analogous in shape, but progressively decrease in size as one proceeds from the outside of the roll inward.

Analysing these damages ${ }^{11}$ has allowed me to infer not only the correct sequence of pezzi, but also to make an approximate estimate of the gaps between one pezzo and another ${ }^{12}$ and therefore of the original length of the roll.

The analysis of the damages of P.Herc. 1067 has also shown that at c. $125 \mathrm{~cm}$ from the end of the volumen the roll broke in half lengthways. As a result, some of the preserved pezzi constitute the upper and lower parts of the same portion of the roll. ${ }^{13}$

Volumetric reconstruction showed that the original roll was c. 13 meters long, ${ }^{14}$ a figure corroborated also by other calculations made on information that was obtained from the old inventories stored at the Officina dei Papiri Ercolanesi. ${ }^{15}$ Of course, of these 13 meters only a fraction remains. Since the roll is missing the upper section and contains a work unknown to us, it is impossible for us to be certain of the precise height of the roll; information obtained from the archive suggests that the roll had a minimum height of c. [30 cm], making it significantly taller than contemporary Greek scrolls, but according with the height we can calculate for the few Latin rolls from the 1st century AD that are known to us. ${ }^{16}$ The length of c. $13 \mathrm{~m}$, however, is very close to the range of dimensions given by Cavallo, with regard to the Philodemus rolls, for the ideal length of 'library rolls', i.e. rolls destined for study in the otium of the library. ${ }^{17}$

And in fact, the script and the correctness of the text unequivocally indicate that this was a volumen of excellent craftsmanship. It is written in an elegant type

11 On the pattern of the folds identified in P.Herc. 1067 and on their characteristic forms, see Piano (2017a) 170-172.

12 Cf. the table in Piano (2017a) 175-176.

13 The pezzi obtained from the final portion are cr. 5 pzz. I and II, cr. 7 pz. II, cr. 8 pz. II, cr. 9 pz. III; the measurements of the circumferences indicate that cr. $5 \mathrm{pz}$. I must be placed above cr. 7 pz. II, and cr. 5 pz. II above cr. 8 pz. II.

14 Piano (2017a) 176.

15 The original length of the volumen, calculated by Piano (2017a) using the appropriate bibliometric techniques, is entirely compatible with the data that can be deduced from the original circumference of the unopened roll, registered in an inventory that goes back to 1782 (published in Blank/Longo Auricchio (2004) 85), as well as with the parameters proposed by Capasso (2007).

16 Piano (2017a) 177-178.

17 In Cavallo (1983) 14-16, and Cavallo (2015) the scholar considers a length of c. 10-12 m to be standard for the Philodemus rolls, all datable within a limited time period in the 1st century BC; in another recent study, he identifies this length as standard for bookrolls to be read in the library; cf. Cavallo (2013) 292-293. 
of rustic capital, widely known because of the many palaeographical studies that are dedicated to this script. ${ }^{18}$ Compared to more formal examples of this type of script, such as that preserved in P.Herc. 1475, the one of 1067 is characterized by a more delicate shading and a slightly more rapid ductus which lends a softer shape to the letters, distinctive also for the significant curvature of oblique downward strokes that incline to the right. The letters, c. $4.5 \mathrm{~mm}$ high, are embellished by empattements at the beginning or end of strokes, and, as usual with this style, the script alternates wide and narrow letters. Even though this hand is similar to that of other Latin Herculaneum papyri, such as P.Herc. $1066,{ }^{19}$ no other pezzi by the same hand have been identified. The most characteristic letter is the $A$, always in three strokes - and not in two as is commonly claimed - with the middle bar reduced to a short slanting leftward stroke that descends from the end of the second stroke. Attested from the 1st century BC onward, this shape is found throughout the 1st century AD and occurs also in some papyri of the 2 nd century. ${ }^{20}$ The precise identification of the sequence of strokes of the $A$ proved essential for reading the subscriptio.

The mise en page of the text is also very neat, with an essentially square writing space consisting of columns presumably [22-23] $\mathrm{cm}$ high and [16-20] $\mathrm{cm}$ wide. These parameters also agree with the most recent palaeographical studies which assert a marked tendency in Latin rolls to place writing in a square space, as opposed to the long and narrow columns typical of contemporary Greek rolls. It suggests that the Romans were more familiar with the format of the codex than with that of the roll. ${ }^{21}$

That the volumen was produced for reading seems confirmed by the reduction of interlinear space, by contrast with the remarkable height of the letters. These features could be explained as the product of an intelligent organization of the writing space, precisely in order to prevent the roll from becoming too long, and so uncomfortable for reading.

The scribe aligns the text only along the left margin, and in the entirety of the recovered text there is no example of word division between successive lines. This

18 For a complete palaeographical analysis cf. Piano (2017a) 178-180 and n. 41 for previous bibliography.

19 Del Mastro (2005) 192 drew attention to the similarity between the two hands, identified by Ammirati (2010) 32.

20 Cf. Piano (2017a) 178 n. 44.

21 Ammirati (2015) 42-43 and 113, Fioretti (2016) 4-5. 
scribal habitus causes a wide range of variation in line length, and consequently in the space between columns, especially in light of the large letter size. ${ }^{22}$

The Latin text exhibits a high degree of linguistic correctness: there are no errors and rare omitted letters are inserted in the interlinear space. There is one marginal note (cr. 2 pz. I sov. 4), probably written by the same hand, but on an extremely reduced scale and with a much faster ductus. Although only a small amount of surrounding text survives, the few extant letters on the same fragment permit the hypothesis that the addition was supposed to rectify a textual omission in a part of the work related to the stuprum of a mulier. ${ }^{23}$

The use of interpuncta is fairly regular and employed exclusively for interword separation. The highly formal nature of the volumen is confirmed by the consistent use of the apex to mark the quantity of long vowels, placed also on diphthongs and monosyllables. Such a correct usage of the apex is paralleled in a few Latin papyri, for the most part of the 1st century, and in inscriptions of highly formal register that date from the end of the 1st century $\mathrm{BC}$ to the beginning of the 1 st century AD. ${ }^{24}$

Other graphic expedients, too, are deployed to articulate the text. In the extant fragments I was able to detect a line written in ekthesis, ${ }^{25}$ one instance of a paragraphos (cr. 2 pz. I sov. 5, col. II ll. 5-6), and three instances of a graphic sign which probably indicated a syntactic pause and is also found in other contemporary Latin papyri. ${ }^{26}$ In one fragment, finally, graphic signs similar in shape to an $M$ are placed in sequence, which do not, however, seem connected to any meaningful string of text; they could have the function of separating two parts of the text. $^{27}$

The classification of fragments in the editio princeps is rather complex. Even though 1067 is one of the better-preserved Latin papyri from Herculaneum, it is

22 For further details on the mise en page of P.Herc. 1067, alongside P.Iand. V 90r (Cic. Verr. 2.2.3-4, 1st century AD.) and P.Berol. inv. 8507 (1st century AD), cf. Piano (2017a) 180-185.

23 In addition to the few surviving letters, the layer of the papyrus in question preserves st]uprata $\cdot$ muliẹ[re rather than st]uprat $\cdot$ muliẹ $[r-$, cf. Piano (2017a) 206-209, with images of the marginal note.

24 See Kramer (1991) for relevant bibliography.

25 In cr. 3 pz. I sov. 1, 1. 8, the verb dixit protrudes to the left by about one letter. The whole fragment is marked by a narrative historical tone, cf. Piano (2017a) 213-214.

26 The sign looks like an oblique downward stroke from right to left, is inscribed within the ideal bilinear writing system, and in two cases is preceded by an interpunctum; this sign is commonly called virgula or comma, cf. Wingo (1972) 50-54. For other instances in contemporary Latin papyri, cf. e.g. P.Iand. V 90 1. 5, P.Berol. 8507 col. II 1. 18.

27 Cr. 5 pz. I, cf. Piano (2017a) 185-186, with image. 
nevertheless in terrible condition. The legibility of the text is complicated, above all, by the confused stratigraphy of the papyrus: almost all 16 pezzi are made up of multiple layers of papyrus that have been become attached to one another. The impression that a conspicuous quantity of text has been preserved is therefore contradicted by a careful inspection of the original which reveals that apparently consecutive, sometimes even aligned, lines of text are in fact written on different layers of papyrus and are therefore separated from one another by the distance of one or more circumferences of the roll. This explains the extreme fragmentary nature of the text and its complicated classification. Every textual fragment is identified, firstly, by the number of the cornice and the pezzo to which it belongs, indicated in the edition by the abbreviations $\mathrm{cr}$. and $p z$. respectively; there follows the indication sovrapposto and Arabic numerals in ascending order. This system was adopted in order to avoid giving equivocal information to the reader and to produce an edition that reflects as closely as possible the stratigraphy of the papyrus. If, in fact, it was possible for individual pezzi to infer their original order, the same was not possible for the layers of papyrus that contain the fragments of text. The different layers now prove to overlap over one another in such a high number and such a complex fashion that it is often impossible to determine the relative order of textual fragments written on different layers.

\section{The auctor of the work: the first line of the subscriptio}

Until 2017 when the editio princeps was published, P.Herc. 1067 was believed to contain an oratio in Senatu habita ante principem. This indeed was the hypothesis advanced by Felice Costabile in the only study dedicated to the contents of the volumen, published in $1984 .{ }^{28}$ The identification, and, in a second step, the correct reading of the ancient subscriptio of the papyrus were central to rebutting this hypothesis. The innermost pezzo of P.Herc. 1067 (cr. 9 pz. III) in fact preserves parts of the final column of the text and, at a certain distance, about half way down the roll, part of the ancient 'title'. The first line is preserved in its entirety, while only few, very incomplete traces of ink of the second remain. The discovery of the subscriptio is owed to Gianluca Del Mastro who published his findings in $2005,{ }^{29}$ in an article dedicated to Latin Herculaneum papyri in general. Costabile

28 Costabile (1984).

29 Del Mastro (2005) 191-192. 
did not in fact note any subscriptio for P.Herc. 1067, though he did record one for P.Herc. 1475, another Latin papyrus that Costabile studied in connection with 1067 and treated within the same article. ${ }^{30}$ In this second roll Costabile reported the reading of the $L$ of the praenomen Lucius and, immediately afterwards, of $M A$ [, followed in turn, at a distance corresponding to ca. 10 letters, by a $T$. In light of this interpretation, Costabile identified the author of the text as Lucius Manlius Torquatus, Roman politician and follower of Epicureanism who died among the ranks of the Pompeians in $46 \mathrm{BC}{ }^{31}$

In 2005, however, Del Mastro noticed that the $L$ and the traces of the letters $M$ and $A$ that Costabile claimed to have read at the end of P.Herc. $1475,{ }^{32}$ were in fact preserved at the end of P.Herc. 1067. Del Mastro upheld Costabile's reading, but hypothesized that there had been a confusion between the final pezzi of the two papyri at the time when Costabile was working on P.Herc. 1067 and 1475. This confusion led to the erroneous attribution of the work contained in P.Herc. 1067 to the alleged author previously identified in 1475, since the traces of writing which were linked to the name of Lucius Manlius Torquatus were found not at the end of P.Herc. 1475, but of papyrus 1067.

Beginning in 2005, therefore, it was widely believed among scholars that P.Herc. 1067 contained an oratio in Senatu habita ante principem composed by Lucius Manlius Torquatus. As a matter of fact, Robert Marichal had already identified and partially transcribed the subscriptio of 1067 before Del Mastro. This discovery, however, along with a transcription of this subscriptio, which differed from that of Costabile and Del Mastro, remained unpublished and was therefore not known to Del Mastro, either. Marichal dedicated about forty years of research to the Latin Herculaneum papyri, but the results of this tremendous endeavor have unfortunately remained unpublished. ${ }^{33}$ At this time, however, his notes on Herculaneum can be consulted at the École Pratique des Hautes Études, where

30 P.Herc. 1475 has been recently edited by Essler (2019).

31 For all this and for the new reading of the first line of the subscriptio of P.Herc. 1067 see Piano (2016).

32 The autoptic inspection of P.Herc. 1475 allowed me to verify the effective presence of a subscriptio in the papyrus, preserved, however, not in the last cornice, as Costabile (1984) 597 claimed, but in cr. 7, which indeed preserves the final part of the roll (cf. MSI 1475 CR 07 1109211093), cf. Piano (2016) 276; for a partial reading of the subscriptio see Essler (2019) 144-147, who identifies the work as a Commentarium.

33 I was able to study the Herculaneum section of the Marichal Archive in 2015, thanks to a collaboration between PLATINUM ERC-StG and the École Pratiques des Hautes Études of Paris; preliminary results on that topic have been published in Piano (2017b). 
the entire Marichal archive is kept. ${ }^{34}$ Apart from a careful evaluation of the readings proposed by Costabile in 1984, the papers of Marichal concerning P.Herc. 1067 contain the transcription of all the pezzi; among these there is also the - rather laborious - transcription of the two lines that apparently escaped Costabile's notice, which were not part of the text of the work but were written "vers le bas" - as Marichal notes - of the final pezzo of the papyrus - pezzo III preserved in cornice 9.

A preliminary transcription contains $\operatorname{EXVN} . A \ldots$ in the first of the two surviving lines, and an $N$ at the beginning of the second line, followed, at some distance, by an $R$.

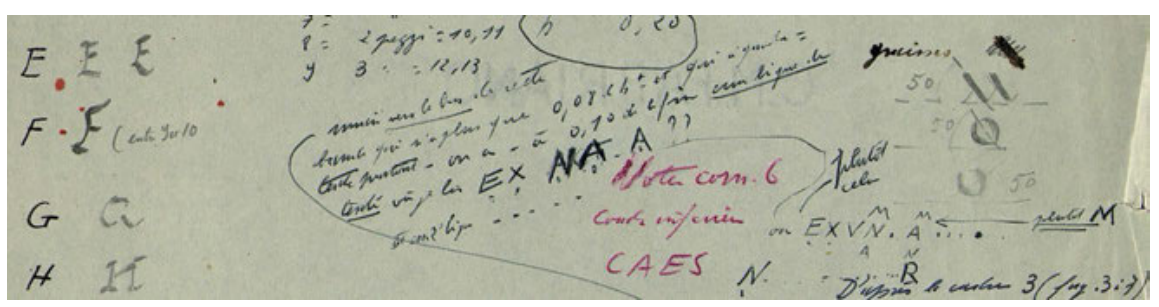

Fig. 1: Archives Robert Marichal (image no. EPHE_PLATINUM_09_0496): first attempts of transcription of the first line of the subscriptio; on the right, the transcription quoted above. (C) PLATINUM-EPHE

Another sheet from the Archive, dedicated entirely to the final pezzo of the roll, contains a very accurate drawing of the end of the volumen with traces of ink still visible and a transcription, certainly more scrupulous and therefore later, that differs from the first version. In it, the scholar wrote, on two lines respectively

\begin{tabular}{crc}
\multicolumn{4}{c}{$\mathrm{L}[\cdot]$} & ANNA $[\ldots] \cdot[$ \\
] NT & $\mathrm{R}$ & $\mathrm{P}$
\end{tabular}

34 For an analysis of the portion of the Archive that relates to the Latin papyri see Scappaticcio (2017) which also contains a new inventory edited by Océane Valencia. 


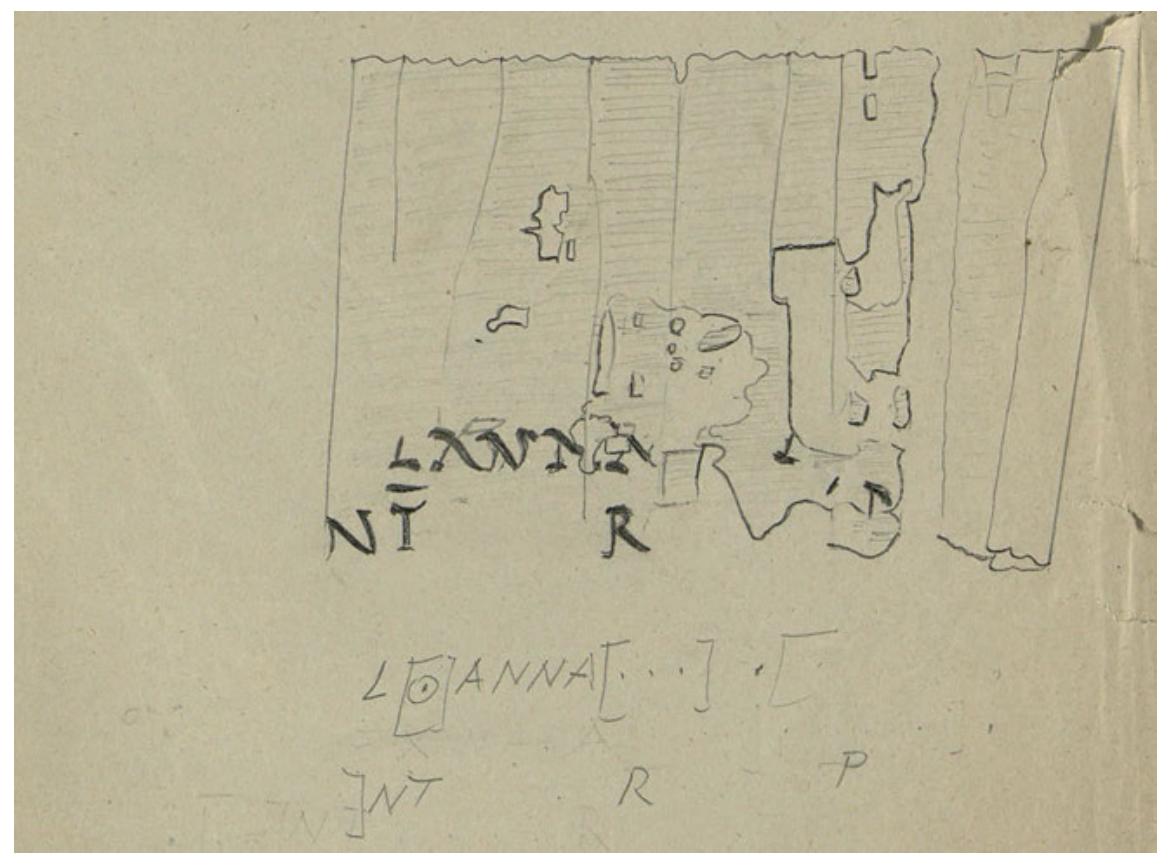

Fig. 2: Archives Robert Marichal (image no. EPHE_PLATINUM_09_0495): definitive transcription of the subscriptio. OPLATINUM-EPHE

Instead of L. Ma[, Marichal read L. Anna[ and therefore understood that the work was written by a Lucius Annaeus. Doubts remained on which of the Annaei could be its auctor. Marichal himself in fact drew up a list of three possible Annaei who shared the praenomen Lucius: the first name is that of Lucius Annaeus Cornutus, followed by Seneca the Elder - whose name is flagged with a question mark, since his praenomen was uncertain - and Seneca the Younger whose praenomen was certainly Lucius. ${ }^{35}$

This, then, was the situation in 2016, when I began to examine P.Herc. 1067 in person.

From the autoptic inspection of the last pezzo of the roll it emerged immediately that Marichal's second, unpublished reading, L(uci) Anna[ei, was much more compatible with the original as compared with the alternative reading, L(uci) Ma [nli. In the rustic capital of P.Herc. 1067, the form of letters such as A, $M$, and $N$, are somewhat similar and can easily be confused. But there is a detail

35 Cf. Marichal, Archives, image no. EPHE_PLATINUM_09_0494. 
which, once identified, allowed me not only to corroborate Marichal's reading, but also to build on it and attribute the work to Lucius Annaeus Seneca with certainty.

The identification of the third stroke of the $A$, which, as mentioned above, is characteristic of the letter in the script of P.Herc. 1067, permitted the certain identification of an $A$ in place of the $M$ read by Costabile and Del Mastro. Following the $A$, the traces, partial but unmistakable, of two Ns can be made out, followed, in turn, by another $A$. After this second $A$ - the last letter read by Marichal in the first line - very slight traces of the $E$ of the diphthong can be made out. It has confirmed the reading L(uci) Annae[i.

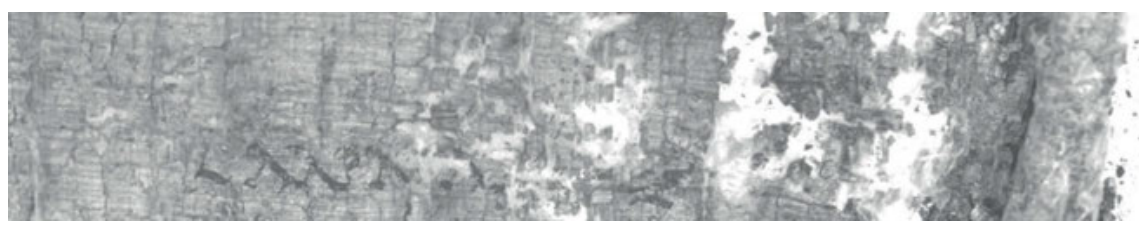

Fig. 3: P.Herc. 1067, cr. 9 pz. III: first line of the subscriptio. (C) Biblioteca Nazionale di Napoli Brigham Young University, Provo, USA

It remained to choose between the chronologically admissible Lucii Annaei. The breakthrough in this question came with the decipherment of the traces of ink after the gap following the diphthong $A E$ that had been ignored by Marichal, and, above all, with the correct stratigraphic analysis which allowed me to understand that the original position of these traces was different from their current one.

The traces in question are compatible with the remnants of an $A$, as the unmistakable third stroke of the letter shows, followed by an $E$. The virtual placement of this sovrapposto moves the letters to the end of the line, and therefore to a position compatible with a genitive singular in $-A E$, and establishes a gap between Annae[ and ]ae perfectly bridged by the name $L[\cdot]$ Annae[i $\cdot$ Senec]ae.

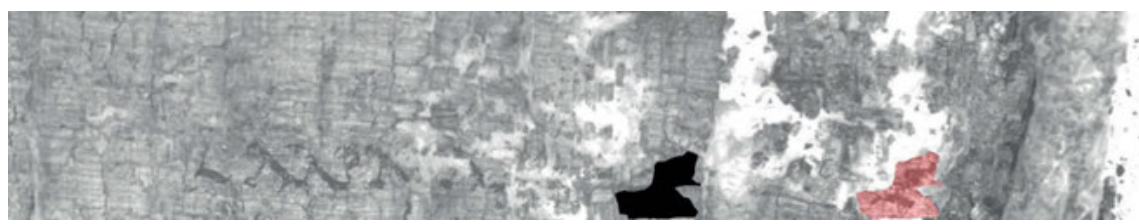

Fig. 4: P.Herc. 1067, cr. 9 pz. III: first line of the subscriptio with the repositioning of a sovrapposto. (c) Biblioteca Nazionale di Napoli - Brigham Young University, Provo, USA 
The complete text of the first line of the subscriptio allowed me to reduce the list of possible auctores to Seneca senior and Seneca iunior, both of whom are chronologically acceptable.

\section{The contents of the work}

The choice of Seneca the Elder was guided, above all, by the contents of the text which slowly emerged during my autoptic inspection of the pezzi: it was soon possible to deduce that the text was of historical and political nature. Among the various thematic units, the prosopographic one, which belongs to a senatorial context of the Augustan or Tiberian age, is particularly suggestive. There are numerous mentions of members of the Julio-Claudian gens (or of Imperial titles which refer to them), rendered even more significant by the extremely fragmentary nature of the text. The mention of Tiberius is particularly striking: it is crucial for both chronological and thematic purposes, and occurs almost at the end of the original volumen.

\subsection{Caés[a]re, bellọ· Gall[ico: cr. 6 pz. II, sovv. $1+2$}

Proceeding from the beginning of the roll, the first instance relevant for our purposes is that of the term Caés[a]re, already identified by Marichal and Del Mastro in the pezzo contained in cr. $6 \mathrm{pz}$. II, ${ }^{36}$ which occurred about half way through the roll, approximately speaking. Apart from Caés[a]re, the inspection of the original also permitted me to identify the term bell[ in the following line, whereas the examination of the stratigraphy led me virtually to join the layer of papyrus containing Caés[a]re and bell[ with another layer placed at the same height but in the following circumference; the two layers are perfectly compatible when joined. The textual fragment obtained by joining the two layers restores Caés[a]re and bello - Gall[ to two consecutive lines of the column. The string GALL/ can refer to a proper name, but given the presence of bello immediately preceding Gall[, it seems inevitable to supply bello $\cdot$ Gall [ico. ${ }^{37}$ In all surviving literary instances, the expression constituted by the noun bellum and the adjective Gallicum refers to

36 Marichal, Archives “4_MAR 175” and image no. EPHE_PLATINUM_09_0496, on which see supra Fig. 1, and Piano (2017b) 39, and tab. 3; Del Mastro (2005) 191.

37 For further details see Piano (2017a) 198-202, with related images. 
the wars in Gaul that lead to its conquest and, thus, end with the famous campaign of Gaius Julius Caesar. It seems thus plausible to take this as a reference to that event. On the other hand, since the other prosopographical elements in the papyrus all refer to the principate of Augustus or Tiberius, a potential reference to Caesar's Gallic war would be strictly cursory. ${ }^{38}$ It is also possible to hypothesize a reference to the campaigns in Gaul undertaken by Augustus or Tiberius during their rule, ${ }^{39}$ but in this case the sources never speak of a bellum Gallicum properly, even though the single word bellum can be used to refer to a rebellion or a sedition.

\subsection{Augustus, Haterius, and the Senate: the fragments of cr. 2 and cr. 3}

That the mention of the Gallic war is an isolated reference is demonstrated by the presence, not far from the joined fragments, of the first of the two instances of the term Augustus. It occurs in the dative or ablative (A]ụ[g]usto, cr. 2 pz. I sov. 2, 1. 2); unfortunately, on the same layer of papyrus only few other letters survive, which are not significant in terms of sense. ${ }^{40}$ The same pezzo of cornice 2 preserves other noteworthy textual fragments. In addition to the possible, but unverifiable mention of Aeneas, ${ }^{41}$ and the reference - isolated, unfortunately - to the stuprum of a mulier, written in part in a marginal note, ${ }^{42}$ there is a more extensive fragment that mentions one Haterius. The name, partially preserved but certain, appears in a fragment certainly set in the Senate: ${ }^{43}$ the strings rogab [ and ut $\mathrm{Ha}^{\prime} \mathrm{t}^{\prime}$ [eri- suggest a senatorial discussion in which Haterius took part. Since the

38 Cf. Lucarini (2018) 88-89, who supposes that Seneca might have mentioned Julius Caesar's Gallic war in connection with the campaign undertaken by Tiberius in the Eastern part of the Gauls just after his adoption in $4 \mathrm{AD}$.

39 So Scappaticcio (2018) 1061-1062, who interprets the fragment with reference to Tiberius' intervention in Gaul in $21 \mathrm{AD}$ to pacify the rebellion animated by Julius Florus and Julius Sacrovir (cf. Tac. ann. 3.40-47).

40 Piano (2017a) 204-205.

41 Cr. 2 pz. I sov. 3 (?), col. I ll. 2-5: ]s $\cdot$ malus $\mid$ ]rus $\cdot$ captam | ]le ...[ ]| ]enẹam, for which one reference to Aeneas (1. 5: Aleneam) and one to the sack of Troy (taking captam in 1.3 in connection with a potential Troiam) have been proposed entirely hypothetically; it should be noted that the fragment might belong to the same column where I read A]ú[g]usto (cr. 2 pz. I sov. 2), as explained in Piano (2017a) 205-206.

42 Cf. supra n. 23.

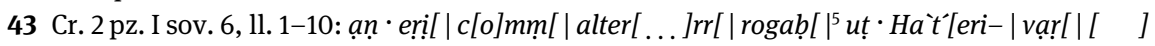

I[ | |] șena[t-| $\left.\left.\right|^{10}\right]$ vet [·] sẹn. [; cf. Piano (2017a) 210-212. 
praenomen is not mentioned, the identification is not certain, but it is quite probable that this is Quintius Haterius, ${ }^{44}$ one of the most famous Roman orators living between the first centuries BCE and AD (d. 26 AD), who was very close to Seneca the Elder and in whose rhetorical work he features several times. ${ }^{45}$

Another certain mention of the Senate is found in a subsequent fragment, cr. 3 pz. I sov. 3, where 1. 8 reads Senátu[. The string Gall[ is found again on another layer of papyrus which perhaps was part of the same column of sov. 3. The proximity of the two occurrences in this case militates against postulating a second mention of Gaul, suggesting, instead, a proper name. The distance between these fragments and the fragment containing the mention of Haterius cannot be calculated owing to the muddled stratigraphy of the papyrus but might be limited to a few columns. ${ }^{46}$

\subsection{Apostrophe to the princeps: cr. 5 pz. I sov. 1}

The most interesting fragments from a textual point of view come from the two pezzi stored in cornice 5, which must have been located near the end of the roll. The first of the two, cr. 5 pz. I sov. 1, is the most extensive fragment that it has been possible to recover from the papyrus and the only one where we can grasp the syntactic structure of a sentence. The fragment preserves portions of two consecutive columns and in line 3 of the first column the vocative Auguste is clearly visible. Indeed, it had already been read by Bassi and confirmed by Costabile, ${ }^{47}$ who thought of an oratio in Senatu habita ante principem precisely on the basis of this vocative. In this case, too, the surrounding scraps of text ${ }^{48}$ allow us to hypothesize a senatorial scene (col. I1. 1: nostr L), in which the speaker addresses the princeps declaring that he does not want to stray from the key point of his speech

44 Lucarini (2018) 89-90, who accepts this identification, proposes to connect the mention of Haterius with a discussion concerning the adoption of Tiberius held at the Senate in 4 AD. Scappaticcio (2018) 1065-1068 suggests a possible mention of Haterius Agrippa, son of Quintus Haterius, without excluding a reference to the father in any case.

45 Sen. contr. 1.6.12; exc. 4, praef. 6-11; 7.1 .4 and 24; 7.2.5; 7.8.3; 9.3.14; 9.4.16; 9.6.8 and passim; 10.5.24. Sen. suas. $2.14 ; 3.7 ; 6.1-2 ; 7.1$.

46 In this regard it is worth recording the episode from the third suasoria, set in the Senate, in which the orator Junius Gallio mentions Haterius to Tiberius as an orator characterized by excessive vehemence in his declamations (suas. 3.6-7).

47 Bassi (1926) 211; Costabile (1984) 594-595.

48 Cr. 5 pz. I sov. 1, col. I: ] nostṛ[ | ne $\cdot$ l]ọngius $\cdot \hat{a} \cdot$ propp [osito] | ]ḍam $\cdot$ Auguste $\mid]$ ụt $\cdot$ repetam ·

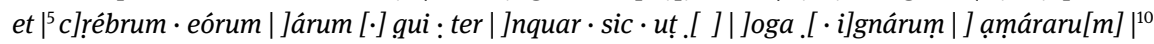
]. inẹes $\cdot$ șolo[ $] \mid] \ldots . . .[$. 
more than is necessary (11. 2-3: [ $\pm 10-15$ ne $\cdot$ l]ongius $\cdot a ́ a$ propp[osito] $\mid[ \pm 14-20$ rece]ḍạ $\cdot$ Auguste, or $[ \pm 10-15$ ne $\cdot$ l]ọngius $\cdot \hat{a} \cdot$ propp [osito] [ [recedam $\pm 7-12]$ dam - Auguste); this rhetorical trope is paralleled most closely in the De Clementia. ${ }^{49}$

There follow the terms c]rébrum, i]gnárum and ạ̣áraru[m (col. I 11. 5, 8-9), which seem to refer to an unhappy situation, perhaps "thick" with unpleasant events, probably concerning the Augustus named in 1. 3. Another possible thematic clue in this regard could come from the following column, where references to adoption and to an act of reproaching, expressed by the verb exprobrare, occur in two consecutive lines (col. II 11. 5-6: [a]doption[, [e]xprobray D). It is difficult to imagine that this verb refers to a polemic addressed by the speaker to the princeps, more likely, instead, that this is a comment, perhaps by the author rather than the speaker, probably related to difficulties in connection with an act of adoption.

In this case, too, the text does not offer other indications for a more precise contextualization. Nevertheless, it is interesting to note its resemblance to a passage placed at the end of the fourth controversia of Book 2 . As happens frequently in the work of Seneca rhetor, the topic of adoption is central to the entire controversia which is centered around the accusation brought by a son against his father for having adopted the grandson born by another son of his and a meretrix. Following the controversia, however, Seneca introduces a brief digression which, in spite of taking the case itself as its point of departure, launches into a moralizing commentary of historical and political nature and ends up being rather unrelated from the events narrated. The motive adduced for this excursus is of course didactic. In a desire to set beside examples to be emulated also examples to be avoided, Seneca records a striking mistake committed by Latro during this case, which could have caused damage not only to his argument but also to his very life (contrariam rem $<$ non $>$ controversiae dixit, sed sibi). Though he was declaiming in the Senate in the presence of Augustus and Marcus Agrippa whose sons were about to be adopted by the princeps, Latro, in taking the side of the son opposed to the adoption, made use of arguments against the practice of adoption in general which proved very offensive to Agrippa, by saying iam iste (i.e. the adopted puer) ex imo per adoptionem nobilitati inseritur, and other things in the same vein (<et> alia in hanc summam). Seneca goes on to explain how Maecenas tried to put an end to the embarrassing

49 Sen. clem. 1.5.1: longius videtur recessisse a proposito oratio mea, at mehercules rem ipsam premit; cf. also Cic. fin. 5. 85.11-12: tamen aberramus a proposito, et, ne longius, prorsus, inquam, Piso, si ista mala sunt, placet. 
scene, and in so doing introduces a number of details that suggest that he witnessed the episode in person. ${ }^{50}$ He concludes with a eulogy of Augustus in a moralizing tone tinged with nostalgia: tanta autem sub divo Augusto libertas fuit ut praepotenti tunc M. Agrippae non defuerint qui ignobilitatem exprobrarent. ${ }^{51}$

For however much the narrative frame and the didactic purpose attributed to the episode color its presentation as simply an anecdote connected with the controversia, the historical details that it contains, which resemble cr. 5 pz. I sov. 1 linguistically and thematically, outline a plausible setting for the terms that survive in this fragment. On the other hand, the well-known events connected with Augustus' succession contained such a close sequence of suspicious occurrences and, consequently, of political maneuvers that inevitably gave rise to various types of reproach, not least at the hands of observers who embraced opposing points of view. In this regard the following passage of Tacitus, concerning the discontent felt by Livia at Tiberius' obligation to adopt Germanicus, is revealing: Nam dubitaverat Augustus Germanicum, sororis nepotem et cunctis laudatum, rei Romanae imponere, sed precibus uxoris evictus Tiberio Germanicum, sibi Tiberium adscivit; id que Augusta exprobrabat, reposcebat (Tac. ann. 4.57.3).

In combination these passages seem to suggest the general climate characteristic of the Augustus' succession. The two terms [a]doption[ and [e]xprobray [, attested, significantly, in succession in col. II of cr. 5 pz. I sov. 1, in addition to the negative expressions that accompany the apostrophe to the princeps in the preceding column, might refer to this climate. The fragmentariness of the text implies this hypothesis must be considered one of many possibilities, including, of course, the alternative of taking the vocative Auguste to refer to Tiberius ${ }^{52}$ and the expressions [a] doption[- and [e]xprobrạ [ of the following column to refer to an adoption that cannot further be specified..$^{53}$

\subsection{Tiberius: $\mathrm{cr} .5 \mathrm{pz}$. II sov. 1}

The hypothesis of a reference to Augustus' succession in cr. 5 pz. I sov. 1, finally, would also be consistent with the final definite mention of a member of the Julio-

50 Zanon Dal Bo (1986) II 247 n. 21.

51 Sen. contr. 2.4.12-13.

52 So Scappaticcio (2018) 1071-1072; by contrast, Lucarini (2018) agrees in identifying the vocative Auguste as a reference to Octavianus, and also associates cr. 5 pz. I sov. 1 with his succession.

53 It is perhaps redundant to observe that if the Auguste of col. I is identified with Tiberius it seems rather improbable that the adoptio of col. II is that of the very same princeps. 
Claudian gens, i.e. Tiberius. The name of the princeps in the nominative is written in clear letters just after a form of the verb destinare in a fragment preserved in line 8 of cr. 5 pz II sov. $1 .{ }^{54}$ It seems worth mentioning that the fragment in question must have followed the preceding apostrophe to the princeps along with the associated reference to adoption by a few columns; moreover, it must have been no more than a few columns from the end of the volumen. The text surrounding Tiberius, however, does not shed light on the context: the only significant lexical element is the form of the verb destinare that precedes the mention of the emperor (cr. $5 \mathrm{pz}$. II sov. 1, 1. 7: ] destinat [-). The small distance between this fragment and cr. 5 pz. I sov. 1 makes it possible that the context is still the same and that, therefore, the verb destinare could refer to the adoption of Tiberius $(4 \mathrm{AD})^{55}$ or to his effective succession to Octavian Augustus in $14 \mathrm{AD}$. An interesting parallel is found in Suetonius' Life of Caligola, in a passage that bears a close resemblance with the passage from Tacitus mentioned above with regard to the exprobratio of Livia, in which the verb destinare appears in connection with Tiberius, once again in reference to the double adoption of Tiberius by Augustus and of Germanicus by Tiberius: sic probatus (sc. Germanicus) et dilectus a suis, ut Augustus - omitto enim necessitudines reliquas - diu cunctatus an sibi successorem destinaret, adoptandum Tiberio dederit (Suet. Cal. 4.1).

\section{The title of the work: the second line of the subscriptio}

The text of P.Herc. 1067 must have ended a few columns later (perhaps three or four at most); of the last there remain a few meagre strings of text, belonging to its upper half, unfortunately inconclusive in terms of sense, followed at a distance of $\mathrm{c} .10 \mathrm{~cm}$ by the subscriptio of the work.

Before returning to the ancient 'title' placed at the bottom of the volumen, and in particular to its second line, it is worth stressing a quantitative fact: at least 11 of the recovered fragments belong to historical and political contexts, ${ }^{56}$ and

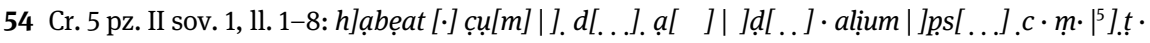
pléniș | ]átur · cum | ]destinaț[- ] | ]. Ṭiberius.

55 Hypothesis accepted by Lucarini (2018), who supposes that the entire book contained in P.Herc. 1067 concerned the historical events happened in $4 \mathrm{AD}$.

56 Cr. 6 pz. II sov. 1 + sov. 2; cr. 2 pz. I sov. 2; sov. 6; cr. 3 pz. I sov. 3; sov. 4; sov. 7 (?); sov. 8; cr. 4 pz. I sov. 2; sov. 4; cr. 5 pz. I sov. 1; cr. 5 pz. II sov. 1. 
around 10 are characterized by narrative or historico-narrative aspects, ${ }^{57}$ featuring a prosopography entirely linked to the Julio-Claudian family and the senatorial aristocracy connected to it in the very first decades of the empire, with the exception, perhaps, of the possible mention of the Gallic War.

The marked prevalence of historical and political themes and, on the other hand, the rarity if not absence of relevant philosophical expressions favor Seneca the Elder as the author of the work. The choice of his historical work rather than a lost part of his rhetorical one derives, in turn, in first place from the chronology based on prosopographical information, which, though spread across fragments that are often far apart from one another, is attested for the entire length of the roll and unequivocally points to a limited period of time. This impression, corroborated by other textual aspects, has received substantial confirmation from the interpretation, advanced in the editio princeps, ${ }^{58}$ of the feeble and fragmentary traces of ink preserved in the second line of the subscriptio that originally contained the title of the work.

Despite the problems associated with determining the exact titles of ancient works, the few traces of ink surviving in 1.2 are not at all compatible with the title of Seneca's rhetorical work that we know: Oratorum et rhetorum sententiae divisiones colores. ${ }^{59}$ On the contrary, the same traces are surprisingly compatible with the title which a number of critics have assigned to the historical work of Seneca the Elder, based on his son's evidence: Historiae ab initio bellorum civilium. ${ }^{60}$

57 Cr. 6 pz. II sov. 1 + sov. 2; cr. 2 pz. I sov. 3; cr. 3 pz. I sov. 1; sov. 7 (?); sov. 8; cr. 4 pz. I strato 1; cr. 5 pz. I sov. 1; cr. 5 pz. II sov. 1; sov. 2; sov. 3.

58 Piano (2017a) 242-244.

59 Piano (2017a) 246 n. 147.

60 Appendix - T1; on this fragment, see FRHist comm. ad loc., Winterbottom (2013); on the possibility of understanding the phrase historiae ab initio bellorum civilium as the title of the work, cf. Canfora (2015) 138-213. 


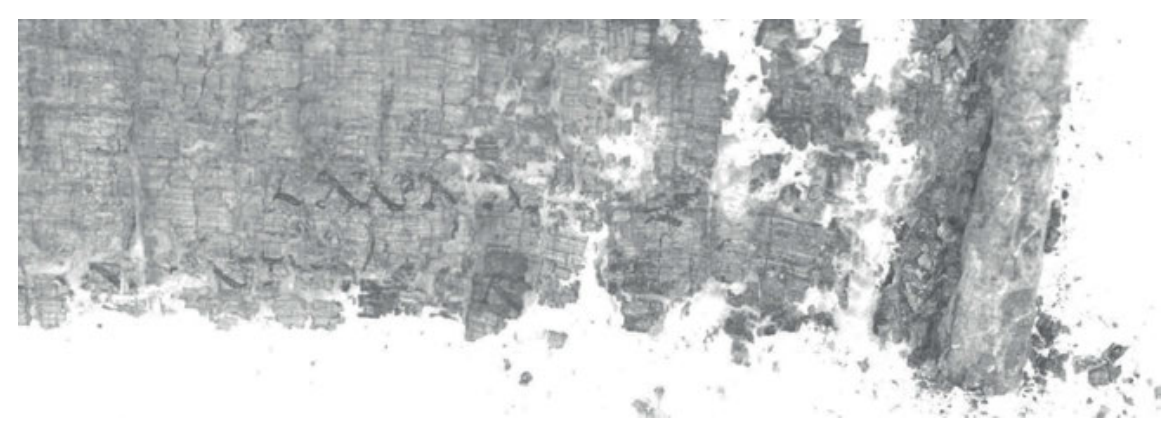

Fig. 5: P.Herc. 1067, cr. 9 pz. III: the extant two lines of the subscriptio. (C) Biblioteca Nazionale di Napoli - Brigham Young University, Provo, USA

Though thin and in an almost desperate state of preservation, the best-preserved graphic signs of the second line are highly suggestive in this connection: the traces of the first letter are compatible with an $A$ (and less probably with an $R$ ), followed by indistinct traces for a space of two letters. The following traces are among the best-preserved of the line and almost certainly belong to an $N$ (less probably a $U$ ), followed by two narrow letters, which can easily be restored as a $I$ and a $T$. After a gap sufficient for a single narrow letter, the lower part of a wide and round letter can be made out, resting on the notional baseline, which could be an $O$, after which only indistinct traces remain. At a short distance from the possible $O$, an $R$ is clearly visible and, immediately after it, the beginning of a $U$ : these two letters are however placed on a sovrapposto and must be virtually transposed to the gap visible in the subsequent circumference of the roll. The digital reconstruction demonstrates that, once the sovrapposto has been moved, the $U$, the body of which falls almost entirely in the gap, is very close to traces of triangular shape visible in the upper part of the line, which would suit the $M$ required by the preceding letters, allowing us to restore the string $-R U M$ near the end of the line. These traces and the gaps which are created by the virtual transposition of the sovrapposto are perfectly compatible with $A b[\cdot[\cdot]$ initịo $[\cdot$ bello]rum.

After the possible $M$, the papyrus is too damaged for us to make out whether there are other traces of ink. Some material aspects of the roll and the mise en page of the subscriptio encourage the supposition that there was still space for a short word: to be specific, inserting the word civilium would perfectly center the 
first line over the second, in accordance with a practice attested for the 'titles' of ancient books. ${ }^{61}$

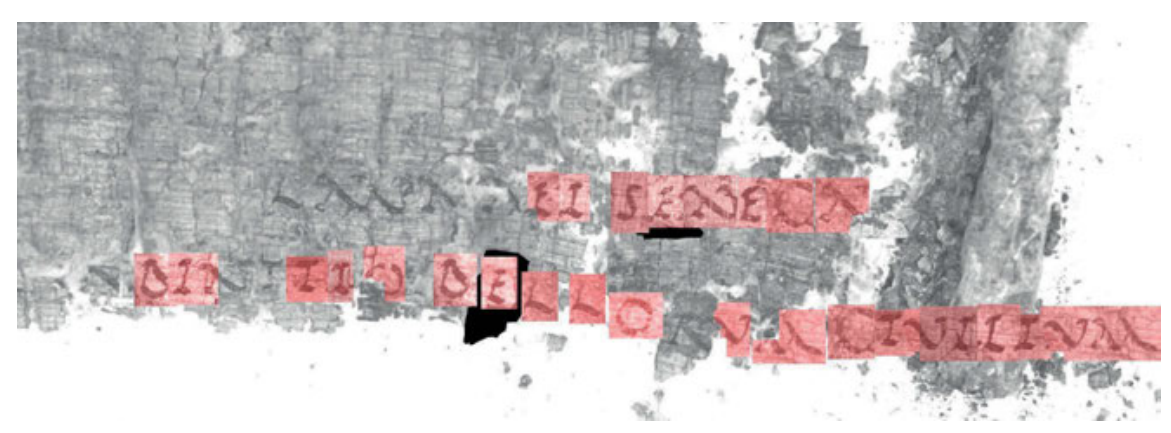

Fig. 6: P.Herc. 1067, cr. 9 pz. III: supplemented subscriptio. The extant letters (or traces of letters) are grey, as well as the two sovrapposti that have been moved to their original positions; letters that have been entirely supplemented are red. ( B Biblioteca Nazionale di Napoli Brigham Young University, Provo, USA

If my hypothesis is accepted as plausible, one could hypothesize the presence, in the third line that has certainly been lost, of a postponed noun on which the expression Ab initio bellorum civilium could be made to depend, or, as Dorandi suggests, of the number of the book of the work. ${ }^{62}$

It is in this way that the disiecta membra and the vestiges of faded letters of an old carbonized book have begun to speak again after almost two thousand years of silence, telling a different 'history' from the one initially assumed. This (hi)story could continue to bring surprises through new combinations of burnt pieces that have yet to be joined together and interpreted in a plausible way.

61 For further observations on the mise en page of the title of P.Herc. 1067, see Piano (2018) 102106; on the ancient 'titles' in Greek Herculaneum papyri see Del Mastro (2014).

62 Cf. Dorandi in this volume, infra 66-67. 